Theories \& Applications, the International Edition

Printed Version : (ISSN 2090-5262)

Online Version : (ISSN 2090-5270)

July 2014, Volume 4, No. 2 Pages (131 - 137)

\title{
The Effect of Different Rates Weight Drills on Muscular Balance for Push Arm and some Kinematic Variables in Shot Put Release Phase.
}

\section{Dr. Khalid Waheed Ibrahim}

Assistant Professor, Sports training department, Faculty of Physical Education, Mansoura University, Egypt.

\begin{abstract}
The purpose of this study is to identify the effect of different rates weight drills on muscular balance for flexor and extensor muscles for push arm and some kinematic variables in glide style shot put release phase. Experimental approach was used with one experimental group sample was intentionally selected form under 20 years Shot Putters at Mansoura Sports Stadium and consisted 6 shot putters. Weight training program applied in special preparation phase for 10 weeks 3 trainings session a week with repetitions from 8 to 12 in 3 sets to 5. Through results presentation and discussion it was possible to conclude the different rates weight training drills led to increase strength of push arm flexors muscles to $359.2 \mathrm{~N}$, and extensors muscles strength to $326 \mathrm{~N}$, which helped to improve muscular balance between them and different rates weight training drills helped to increase release height to $233.33 \mathrm{~cm}$, speed to $11.10 \mathrm{~m} / \mathrm{s}$, and angle to 39.83 degree, and pushing distance to $14.15 \mathrm{~m}$. in glide style shot put.
\end{abstract}

Key word: weight drills - muscular balance - kinematic variables - shot put release phase

\section{Introduction:}

$\mathrm{T}$ The primary objective of shot put competition is too arrival to farthest distance possible without violating competition rules; and this is done through acquiring the shot maximum speed upon releasing it; with getting benefit of most important kinematic variables affect technical performance. So, the maximum speed rate depends on technique used, assembling forces, work to increase shot acceleration during going inside throwing circle (Sloan, 1995) and, about $80 \%-90 \%$ of throwing distance comes through pushing position; therefore appropriate feet pivot distance should be taken during push position to allow access the largest momentum possible as well as get longer path for shot acceleration (Turk, 1997). Pushing position is of the most important and difficult stages of shot put, that is because shot is moved to throwing direction it should go in a straight line and do not veer to one side as shot center of gravity should be in the same direction (Zaki Darwish, Adel Abdel Hafez , 1994( and the release phase begin with right foot and knee rotation forward and then expanding them, buttock moves to outside, right shoulder raise and rotate forward, trunk put (Ballesteros and Alvarez , 1991). The release height, angle and speed are of raise with simple arching, then the right arm put the Shot forward and throwing movement is completed on left leg, which extended when right arm finish extension and shot the most important factors that have greatest impact on shot put distance. Release speed is the key factor affecting distance ( Khalid Wahid, 2004), (Frossard, \& al, 2003) ( Linthorne, 2001) where the shot put distance considered as fixed, release speed decrease $(1.7 \mathrm{~m} / \mathrm{sec})$ for each $(1 \mathrm{~m})$ increment in release height, shot put distance decrease $(1.7 \mathrm{~m})$ (1 degree) increment in release angle and increase $(1.3 \mathrm{~m})$ for each $(1 \mathrm{~m})$ increment in release height and ideal release angle is 42 degrees (Hubbard et al, 2001. (

Muscles control body flexion and extension movement, the more powerful muscles the most contractions effectiveness, as this increases power and speed outcome, thus increasing the capacity (Abdul Aziz Elnemr, Nariman ElKhatib, 1996) and there are working muscles and other corresponding muscles regulate motion direction and make movement balanced and accurate; through fixing other parts of body so that required parts can be moved strong and fast (Essam Elwashahi, 1994) .The strong muscles enable athlete to move quickly and increase joints stability by balancing strength of around joints muscles. (Issam Helmi, Mohammed Gaber Briqa,1997). These muscles are working normally in dual form; when a muscle or muscle group contract, the corresponding muscle or muscle group extract at the same time; and at the party moving arrival to ultimate limit to the joint movement, the muscle or muscle group instantaneously contract with what commensurate with the power and speed of moving muscle to stop joint movement in order to protect it from injury. When group of muscles around a certain joint is relatively stronger than the corresponding muscle group around the same joint, this called lack of muscular balance (muscular imbalance) (Fearing and Lincoln, 1997(

Muscular balance is the strength of a single muscle or muscle group and its relative correlation with other muscle or muscle group (Abu Ela Ahmed, 1997), brachial biceps muscle and the brachial triceps muscle work at the same time while elbow joint movement whether by flexing or extending, but in a counter work method for each muscle 
(Fellows, S, J. \& Rack, P. M, 1987), brachial triceps muscle is responsible for elbow joint extending during push stage in shot put competition and elbow joint extension is very fast; so attention must be given to power drills for arm muscles, especially brachial triceps muscle as they have a positive relationship to performance (Terzis et al, 2003), many activities cause strength increase for one muscle group without coincided increase in the corresponding muscles, therefore corresponding muscles should be more trained in order to improve performance and prevent injury (Wathen, 1993), muscular balance development leads to reduction of side distractions and improve record achievement in triple jump ( Raafat Abdel Monsef , 2004), physical preparation drills should include muscular balance drills and tests for each major muscle groups and identify muscular imbalances and work to strengthen it (Chandler and Roetert 1998 (

There is positive correlation between strength balance for flexor and extensor muscles and speed; so when designing strength programs, it is important to choose drills that work to strength muscle groups on both body sides so that competitor joints are surrounded by muscles development in balanced; as maintaining muscles in true balance with strength increase is the first requirement for development of muscles ability to produce maximum strength with maximum movement range of the highest speed rate .(Abdul Aziz Elnemr, 1993

The most important benefits of weights training is to increase muscle strength and improve around joints muscular balance and positive effect on athletic performance (Mohamed Abdel Rahim , 1998) and the following weightlifting drills (Bench Press, Half Squat and Power Snatch) improve muscle ability (Reis and Ferreira, 2003), weight training should be used whenever possible, which includes movements performance with full joint movement range. particular brachial biceps and triceps strength development drills (Mohamed Mahmoud Abdel Dayem, 1993), and through the pilot study conducted by the researcher on (6) under (20) years shot putters in Mansoura Stadium; It is noticed that a difference of approximately $78.4 \mathrm{~N}$ between the strength of brachial biceps responsible for flexing pushing arm 313.6 $\mathrm{N}$ approximately and that for brachial triceps muscle responsible for extension of pushing arm $233.6 \mathrm{~N}$ approximately which means that brachial triceps muscle strength is approximately $75 \%$ of brachial biceps strength. So this study objective is to identify the effect of different rates weight drills on muscular balance for flexor and extensor muscles for push arm and some kinematic variables in glide style shot put release phase. While hypotheses are that different rates weight drills positively affect muscular balance for flexor and extensor muscles for push arm and some kinematic variables in glide style shot put release phase.

\section{Research procedures:}

Experimental approach was used with one experimental group and pre-post measurement in Mansoura University Olympic Village and Mansoura stadium athletic hall, and track and field, pilot studies, pre and post measurements, and main study different rates weight drills has been conducted during the special preparation period within shot putter training program, in the period from September 1st till December 17th, 2012 .sample was intentionally selected form under (20) years Shot Putters at Mansoura Sports Stadium and consisted (6) putters.

Strength measure of arm extensors and flexors muscles: Shot putter stands and back touching wall wooden pieces and his body fixed to it using leather belts from shoulders , trunk and upper arm for measured arm is fixed near the elbow joint and the fist is closed and pass through the leather belt connected to dynamometer which the forearm to be measured fixed to it with ( 90 ) degrees angle, and when measuring flexing muscles strength, dynamometer to be located below the forearm and connected to a series of metal chain fixed with metal crossbar to wall wooden pieces from bottom, and when measuring extensors strength dynamometer to be fixed top of the forearm. (Ahmed Mohammed Khater, Ali Fahmy ElBek, 1996) , (11 ) (Mohammed Ibrahim Shehata, Mohammed Gaber Briqa 1995), ( see figures (1, and 2(

Figure (1)

\section{Strength Measuring method}

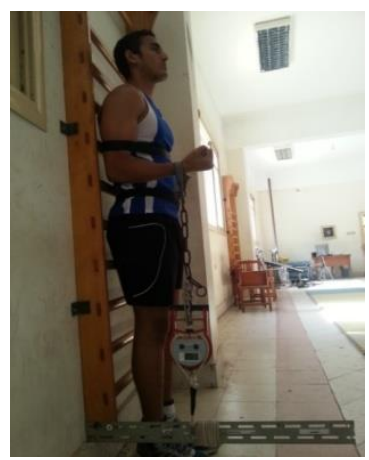

Figure (1) Strength Measuring method

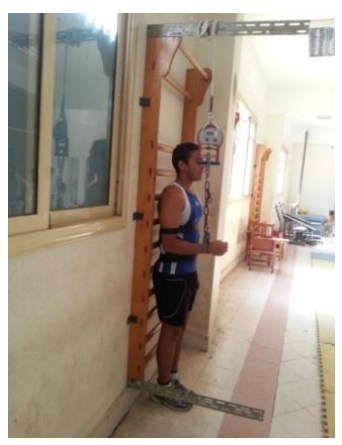

Figure (2) Strength Measuring method 
for forearm flexor muscles

Kinetic analysis done using PC and video point program where (6) attempts filmed for each shot putter, imaging field includes release phase beginning and ending with registration of putters numbers, according to the order of their performance and identify successful and failed attempts and then selecting best successful attempts for each putter in research sample and then these attempts used as for forearm extensor muscles

inputs to the computer software to start the process of kinetic analysis and to define kinematic variables for release phase.

Pre measurements : conducted in the period October 3rd, and 4th, 2012, then researcher confirmed research variables values normal distribution before starting the experiment as shown in tables $(1),(2),(3)$

Table (1)

Statistical characterization of study sample in basic and physical variables (under study) $n=6$

\begin{tabular}{|c|c|c|c|c|}
\hline Variables & Measurement unit & Mean & $\begin{array}{c}\text { Standard } \\
\text { Deviation }\end{array}$ & $\begin{array}{c}\text { Skewness } \\
\text { coefficient }\end{array}$ \\
\hline Age & year & 19.033 & 0.497 & 0.201 \\
\hline Height & $\mathrm{cm}$ & 188.17 & 2.563 & $\mathbf{0 . 1 9 5}$ \\
\hline Weight & $\mathrm{kg}$ & $\mathbf{8 2 . 1 6 7}$ & 2.483 & $\mathbf{0 . 2 0 1}$ \\
\hline training the & year & 4.667 & $\mathbf{0 . 6 0 6}$ & $\mathbf{- 0 . 4 1 3}$ \\
\hline Muscle strength for back extensors & $\mathrm{N}$ & 181.67 & $\mathbf{7 . 5 2 8}$ & $\mathbf{0 . 6 6 4}$ \\
\hline Muscle strength for legs extensors & $\mathrm{N}$ & 273.33 & 17.795 & $\mathbf{- 0 . 7 0 2}$ \\
\hline Wide jump from stability & $\mathrm{cm}$ & 257.50 & 17.672 & $\mathbf{- 0 . 1 7 0}$ \\
\hline High jump from stability & $\mathrm{cm}$ & $\mathbf{5 1 . 5 0 0}$ & $\mathbf{5 . 2 0 6}$ & $\mathbf{0 . 2 8 8}$ \\
\hline shot put in front of body & $\mathrm{m}$ & 11.867 & $\mathbf{0 . 1 2 5}$ & $\mathbf{- 0 . 2 0 0}$ \\
\hline shot put in back of body & $\mathrm{m}$ & 13.792 & $\mathbf{0 . 2 9 2}$ & $\mathbf{- 0 . 8 5 5}$ \\
\hline
\end{tabular}

Table (1) show the basic and physical variables for study sample are normally distributed

Table (2)

Statistical characterization of study sample in muscle strength of pushing arm flexors and extensors muscles in glide style shot put

\begin{tabular}{|c|c|c|c|c|}
\hline Variables & Measurement unit & Mean & $\begin{array}{c}\text { Standard } \\
\text { Deviation }\end{array}$ & $\begin{array}{c}\text { Skewness } \\
\text { coefficient }\end{array}$ \\
\hline Strength of brachial biceps for pushing arm & $\mathrm{N}$ & $\mathbf{3 1 3 . 6}$ & $\mathbf{1 0 . 9 8 3}$ & $\mathbf{- 0 . 2 6 8}$ \\
\hline Strength of brachial triceps for pushing arm & $\mathrm{N}$ & $\mathbf{2 3 3 . 6}$ & $\mathbf{7 . 6 5 8}$ & $\mathbf{- 0 . 4 4 8}$ \\
\hline
\end{tabular}

Table (2) show the values of muscle strength of pushing arm flexors and extensors muscles in glide style shot put variables for study sample are normally distributed

Table (3)

Statistical characterization of study sample in kinematic variables in release phase glide style shot put

\begin{tabular}{|c|c|c|c|c|}
\hline Variables & Measurement unit & Mean & $\begin{array}{c}\text { Standard } \\
\text { Deviation }\end{array}$ & $\begin{array}{c}\text { Skewness } \\
\text { coefficient }\end{array}$ \\
\hline Release height & $\mathrm{cm}$ & $\mathbf{2 2 5 . 5 0 0}$ & $\mathbf{4 . 1 3 5}$ & $\mathbf{0 . 7 2 5}$ \\
\hline Release speed & $\mathrm{m} / \mathbf{s e c}$ & $\mathbf{8 . 8 4 2}$ & $\mathbf{0 . 7 9 4}$ & $\mathbf{- 0 . 3 1 5}$ \\
\hline Release angle & degree & $\mathbf{3 5 . 3 3 3}$ & $\mathbf{1 . 2 1 1}$ & $\mathbf{- 0 . 4 1 3}$ \\
\hline Putt distance & $\mathrm{m}$ & $\mathbf{1 2 . 2 0}$ & $\mathbf{0 . 5 1 8}$ & $\mathbf{- 0 . 2 4 1}$ \\
\hline
\end{tabular}

Table (3) show the values of kinematic variables in release phase glide style shot put variables for study sample are normally distributed
Main study: Conducted during special preparation period of shot putters training program in the period from October 10th, 2012 to December 15th, 2012 for a period of (10) weeks with (3) trainings session a week with repetitions 
from 8 to 12 in 3 sets to 5 , session time ( 2 hours) where following weights have been used:

- (Standing. Face Multi Gem. Wight pulling device caught with both hands in front of body) bend arms.

- (Standing. Face Multi Gem. Wight pulling device caught with right hand in front of body) bend arms.

- (Standing. Face Multi Gem. Wight pulling device caught with left hand in front of body) bend arms.

- (Standing. Face Multi Gem. Wight pulling device caught with both hands upper) bend arms.

- (Standing. Face Multi Gem. Wight pulling device caught with right hand upper) bend arms.

- (Standing. Face Multi Gem. Wight pulling device caught with left hand upper) bend arms.

- (Standing. Arms bent behind head, catching the bar with tight grip) arms extended upper.

- )Standing on the left-leg. Right leg on bench, slant, dumbbells caught with right hand ) bend arm
The ratio of strength training using weights in training session was done with different and counterproductive rates according to amount of muscle strength, where the ratio of drills to develop strength of brachial biceps which work to flex forearm is equivalent to $75 \%$ of those drills for develop strength of brachial triceps muscle, as well as the weights training in different proportions of free arm muscle to consider muscular balance for the two arms together.

\section{Post measurements:}

After completion of main study post-measurements were conducted on December 16th, and 17th, 2012.

\section{Statistical coefficients and factors:}

Mean - standard deviation - Median - skewness coefficient - Wilcokson test $-\mathrm{Z}$ critical value

\section{Results and discussion:}

Results of the pushing arm flexor and extensor muscle strength in glide style shout putt competition after experiment:

Table (4)

Differences significance between pre and post measures of arm flexor and extensor of glide style shot putt competition

\begin{tabular}{|c|c|c|c|c|c|c|c|}
\hline \multirow{2}{*}{ Variables } & \multirow{2}{*}{$\begin{array}{c}\text { Measurement } \\
\text { unit }\end{array}$} & \multicolumn{2}{|c|}{$\begin{array}{c}\text { Pre } \\
\text { measurement }\end{array}$} & \multicolumn{2}{|c|}{$\begin{array}{c}\text { Post } \\
\text { measurement }\end{array}$} & \multirow{2}{*}{$\begin{array}{l}\text { Wilcokson } \\
\text { value }\end{array}$} & \multirow{2}{*}{$\begin{array}{c}Z \\
\text { value }\end{array}$} \\
\hline & & Mean & $\begin{array}{l}\text { Standard } \\
\text { deviation }\end{array}$ & Mean & $\begin{array}{l}\text { Standard } \\
\text { deviation }\end{array}$ & & \\
\hline $\begin{array}{c}\text { Strength of brachial biceps for } \\
\text { pushing arm }\end{array}$ & $\mathbf{N}$ & 313.6 & 10.983 & 359.2 & 9.931 & 0.000 & 2.201 \\
\hline $\begin{array}{c}\text { Strength of brachial triceps for } \\
\text { pushing arm }\end{array}$ & $\mathbf{N}$ & 233.6 & 7.658 & 326 & 13.158 & 0.000 & 2.201 \\
\hline
\end{tabular}

Wilcokson significant at $0.05=17$

Table (4) results reveal presence of statistically significant differences at 0.05 level between pre and post measurements for strength of brachial biceps and brachial triceps for pushing arm, where Wilcokson values were less than its
$\mathrm{Z}$ significant at $0.05=1.96$

significance value at 0.05 level while $\mathrm{Z}$ value was greater than its significance value at 0.05 level.

Results of kinematic variables in release phase glide style shot put after experiment:

Table (5)

Differences significance between pre and post measures in kinematic variables in release phase of glide style shot putt competition

\begin{tabular}{|c|c|c|c|c|c|c|c|}
\hline \multirow{2}{*}{ Variables } & \multirow{2}{*}{$\begin{array}{c}\text { Measurement } \\
\text { unit }\end{array}$} & \multicolumn{2}{|c|}{$\begin{array}{c}\text { Pre } \\
\text { measurement }\end{array}$} & \multicolumn{2}{|c|}{$\begin{array}{c}\text { Post } \\
\text { measurement }\end{array}$} & \multirow{2}{*}{$\begin{array}{l}\text { Wilcokson } \\
\text { value }\end{array}$} & \multirow{2}{*}{$\begin{array}{c}Z \\
\text { value }\end{array}$} \\
\hline & & Mean & $\begin{array}{l}\text { Standard } \\
\text { deviation }\end{array}$ & Mean & $\begin{array}{l}\text { Standard } \\
\text { deviation }\end{array}$ & & \\
\hline Release height & cm & 225.5 & 4.135 & 233.33 & 4.633 & 0.000 & 2.207 \\
\hline Release speed & $\mathrm{m} / \mathrm{sec}$ & 8.84 & 0.794 & 11.10 & 0.535 & 0.000 & 2.201 \\
\hline Release angle & degree & 35.33 & 1.211 & 39.83 & 1.273 & 0.000 & 2.207 \\
\hline Putt distance & $\mathbf{m}$ & 12.20 & 0.518 & 14.15 & 0.370 & 0.000 & 2.201 \\
\hline
\end{tabular}

Wilcokson significant at $0.05=17$

$\mathrm{Z}$ significant at $0.05=1.96$ 
Table (5) results reveal presence of statistically significant differences at 0.05 level between pre and post measurements for kinematic variables in release phase of glide style shot putt competition, where Wilcokson values were less than its significance value at 0.05 level while $\mathrm{Z}$ value was greater than its significance value at 0.05 level.

Figures (3), (4) show release height and angle for one shot putter before and after the experiment.

\section{Figure (3)}

release height and angle for one shot putter before the experiment.

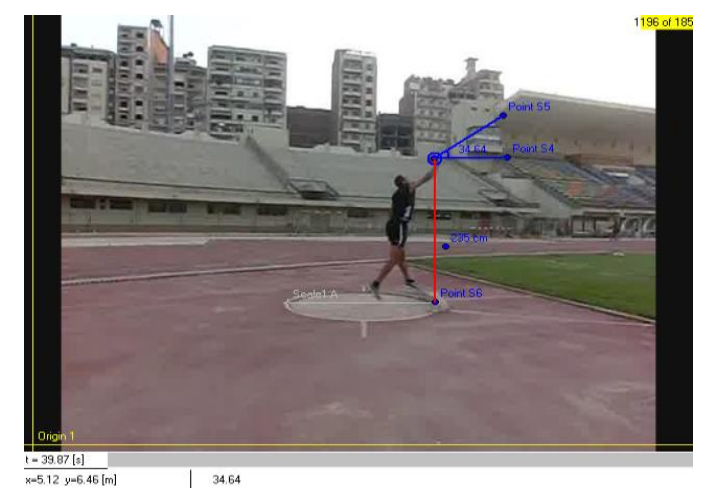

Figure (4)

release height and angle for one shot putter after the experiment

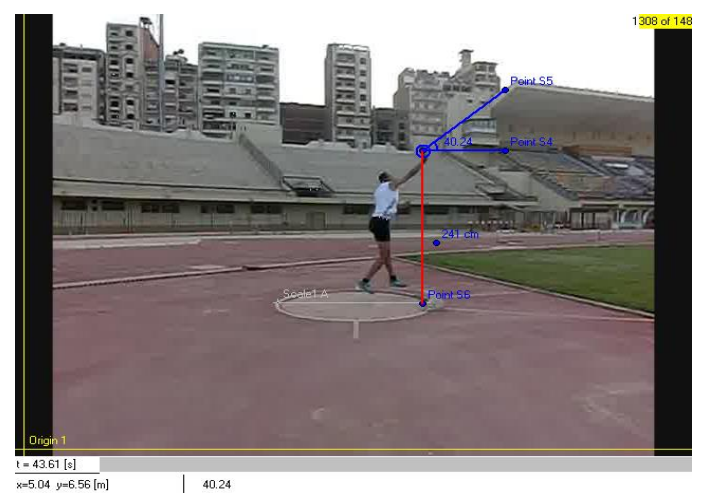

Discussion of pushing arm flexor and extensor muscle strength in glide style shout putt competition results of study sample:

Table (4) results reveal presence of significant differences at 0.05 significance level, in favor of post measurement in strength of brachial biceps for pushing arm; with a mean of $359.2 \mathrm{~N}$ and in strength of brachial triceps for pushing arm, with a mean of $326 \mathrm{~N}$. Researcher return this to the positive impact of different rates weight training, which have been applied during special setup period for shot putters (study sample) which helped to increase strength of arm extensor and flexor muscles; where strength training volume ration in groups used in session was different and counterproductive , according to the amount of muscle strength , where the ratio of drills to develop strength of brachial biceps which work to flex forearm is equivalent to $75 \%$ of those drills for develop strength of brachial triceps muscle, weight drills proportion increased in training session according to this ratio resulting in improved muscular balance between pushing arm flexors and extensors, and this is consistent with what mentioned by (Chandler and Roetert 1998) (Abdul Aziz Elnemr,1993) (Mohamed Abdel Rahim, 1998 (

Discussion of results of kinematic variables in release phase glide style shot put for study sample:

Table (5) results reveal existence of significant differences at 0.05 level in favor o post measurements of kinematic variables of release phase of glide style shot put, where release height mean was $233.33 \mathrm{~cm}$; researcher return this to the effectiveness of different rates weight training, which have been applied during special setup period for shot putters (study sample) which helped to increase strength of arm extensor and flexor muscles and achieve muscular balance between it, which helped to improve pushing arm movement, increasing elbow joint movement range, pushing arm extension to maximum possible height while shot releasing, and organize pushing arm movement in accurate and balanced manner. This is consistent with what mentioned by (Wathen, 1993) (Essam Elwashahi, 1994) (Issam Helmi and Muhammad Briqa, 1997 ) (Mohamed Mahmoud, 1993) (Terzis et al, 2003). Release speed mean was $11.10 \mathrm{~m} / \mathrm{s}$, researcher return this to the effectiveness of different rates weight training, which have been applied during special setup period for shot putters (study sample) which helped to improve muscle contraction effectiveness, increase strength outcome, and in turn increase speed, ability and movement volume, this is consistent with what referred by ( Abdul Aziz Elnemr, and Nariman al-Khatib, 1996) Release angle mean was 39.83 degree, researcher return this to the effectiveness of different rates weight training, which have been applied during special setup period for shot putters (study sample) which helped to increase strength of arm extensor and flexor muscles and achieve muscular balance between it, which helped to improve pushing arm movement, increasing elbow joint movement range, pushing arm extension to maximum possible height while shot releasing, and organize pushing arm movement in accurate and balanced manner. This consistent with what mentioned by (Wathen, 1993) (Essam El Washahi, 1994). Push distance mean was 14.15 meters, researcher attributes this to the the effectiveness of different rates weight training, which have been applied during special setup period for shot putters (study sample) which helped to increase strength of arm extensor and flexor muscles and achieve muscular balance between it, which helped to improve release height, speed and angle, which in turn increased push distance. This is consistent with what mentioned by (Khalid Wahid Ibrahim, 2004), (Frossard et al, 2003) (linthorne, 2001). 
Conclusions

Through results presentation and discussion it was possible to conclude that the different rates weight training drills led to increase strength of push arm flexors muscles to $359.2 \mathrm{~N}$, and extensors muscles strength to $326 \mathrm{~N}$, which helped to improve muscular balance between them and they helped to increase release height to $233.33 \mathrm{~cm}$, speed to $11.10 \mathrm{~m} / \mathrm{s}$, and angle to 39.83 degree, and pushing distance to $14.15 \mathrm{~m}$ in glide style shot put.

Recommendations

In light of research conclusion researcher recommends that the using different rates weights training for pushing arm flexors and extensors muscles, according to each muscle's strength, to improve muscular balance between it in shot put training programs, using various weight training programs with same movement path for pushing arm flexors and extensors muscles during shot put competition due to its effectiveness on technical performance. It is necessary to focus on diversity of methods and means to develop muscle ability of shot putters due to their importance in improving technical performance.

\section{References}

1. Abu Ela Ahmed Abdel Fattah (1997) : sports training and physiological bases, Dar Elfekr Elarabi, Cairo . p.146 (In Arabic(

2. Ahmed Mohammed Khater, Ali Fahmy ElBek (1996) : Measurement in sports field, Modern Book House , Cairo • p.256 . (In Arabic(

3. G. M . Ballesteros , G . Alvarez : Athletics education and training foundations and principles, translated by Osman Refaat, and Mahmoud Fathy Mahmoud, Athletics Regional Development Center, Cairo . p166 . (In Arabic(

4. Khalid Wahid Ibrahim, (2004) : The effect of using pushing machine on some kinematic variables for release in shot put competition, Eighth International Scientific Conference for Physical Education and Sports Science, second part, Faculty of Physical Education for Men, Alexandria University, October 5 to 7 pp. 730755. (In Arabic(

5. Zaky Darwish, Adel Abdel Hafez (1994) : Encyclopedia of athletics, throwing and compound competition, Dar El-Maaref, Alexandria. P.77 (In Arabic .(

6. Raafat Abdel Monsef (2004) : The impact of motor and muscular balance development on side distraction for triple jump distance, unpublished Ph.D. thesis , Faculty of Physical Education for Men, Alexandria University, Alexandria. (In Arabic(
7. Abdul Aziz Ahmed EINemr (1993) : The effect of strength balance between knee joint flexors and extensor muscles on sprint speed, the scientific journal of Physical Education and Sports , No. XVIII , Faculty of Physical Education for Men, Helwan University, Cairo, October p.157 - 170. (In Arabic(

8. Abd el Aziz Abdul Aziz Ahmed Elnemr, Nariman Elkhatib (1996) : Athletic training, weightlifting training, strength program design and training season planning, book publication ccenter, Cairo . p65. (In Arabic(

9. Essam El Washahi (1994) : weights trainingstrength and Championship, Dar ElJihad for publishing and distribution, Cairo - p.131 (In Arabic(

10. Issam Helmi , Mohammed Gaber Briqa (1997): Athletic training (foundations, concepts - trends) , Alexandria. P.10 (In Arabic(

11. Mohammed Ibrahim Shehata, Mohammed Gaber Briqa 1995 : Body measurements manual and motor performance tests , Dar ELmaaref, Alexandria. pp. 60-61 (In Arabic(

12. Mohamed Abdel Rahim Ismail (1998): Muscle strength training and weightlifting programs for children, Dar ELMAaref, Alexandria. P 14 (In Arabic(

13. Mohamed Mahmoud Abdel Dayem, Medhat Saleh Sayed, Tariq Mohammed Shoukry (1993) : Physical preparation and weightlifting training programs, Al Ahram Press, Cairo . p.95 (In Arabic(

14. Chandler,T., Jeff \& Roetert, E., Paul. (1998): Sport Specific Muscle Strength Imbalances Tennis , National Strength \& Conditioning Association .pp.38

15. Fearing ,D., Lincoln ,J (1997): Shoulder Problems - are they due to muscular Imbalance or Repetitive Type Motion , American Journal of Sports Medicine Committee • pp .7

16. Fellows, S, J. \& Rack, P. M. H. (1987) : Changes In The Length Of The Human Biceps Brachii Muscle During Elbow Movements, February 1, The Journal of Physiology. pp $\mathbf{. 4 0 7}$

17. Frossard, L, Schramm, A, Goodman, S. (2003) : Kinematics analysis of Australian elite seated shot-putters during the 2002 IPC world championship : parameters of the shot's trajectory, International Society of Biomechanics XIXth Congress : the human body in motion, 611 July 2003, Dunedin New Zealand, University of Otego • p .115 
18. Hubbar, d, M., Neville, J., and Scott, J., (2001) : Dependence Of Release Variables In The Shot Put , Journal Of Biomechanics, Vol. 34 , issue 4, April , pp . 449 - 456.

19. Linthorne, N., (2001): Optimum Release Angle In The Shot Put , Journal Of Sport Sciences Taylor, Francis Ltd, Vol. 19. pp . 360

20. Reis, M., Ferreira, J., (2003) : The validity of general and specific strength tests to predict the Shot Put performance - a pilot study, International Journal of Performance Analysis in Sport, Volume 3, No 2, 1 December. pp.112 120

21. Sloan,R., (1995) : Developing Shot Put Technique, Track and Field Coaches Review, Vol. 95, No 3 • pp .34
22. Terzis,G. Georgiadis.G., Vassiliadou, E., Manta, B. (2003) : Relationship between shot put performance and triceps brachii fiber type composition and power production, European Journal of Applied Physiology, Volume 90, Issue 1-2 September. pp . 10 - 15

23. Turk, M., (1997) : Building Technical Model Of The Shot Put, Track Coach, No 141, Fall . pp .4798

24. Wathen, D., (1993): Muscle Balance Essentials of Strength Training and Conditioning, Human Kinetics Publishers Inc , Champaign • pp .424 
